\title{
GAYA ARSITEKTUR DI PERUMAHAN DINAS MILITER ANGKATAN DARAT, CIMAHI, JAWA BARAT
}

\author{
Milla Ardiani \\ Architecture Department, Faculty of Engineering, Binus University \\ Jl. K.H. Syahdan No. 9, Palmerah, Jakarta Barat 11480 \\ yanitamila@yahoo.com
}

\begin{abstract}
Cimahi is a city in West Java that owns many relics of the Dutch architectural heritage built in the early 20th century. The majority of buildings are military buildings that have a hierarchy according to the military rank, seen from the styles presented at the army's military housing. The building style has no longer presented either Indische empire style or modern colonial style. The architectural style in the transitional period at that time adapted the tropical climate of Indonesia with the visible formation of the Dutch. This paper is the result of research done by observation and a survey at the Army Military Housing, Cimahi, West Java. Data were analyzed quantitatively to analyze the number of houses and ornaments dismantled and its original form. In addition, qualitative methods are also used to analyze the demolitions done by the building occupants.
\end{abstract}

Keywords: Cimahi, military housing, transitional architectural style

\begin{abstract}
ABSTRAK
Kota Cimahi memiliki banyak peninggalan karya arsitektur warisan Belanda yang dibangun di awal abad 20. Mayoritas bangunan merupakan bangunan militer. Bangunan militer ini memiliki hirarki sesuai kepangkatan militer, terlihat dari gaya yang dihadirkan di perumahan dinas militer angkatan darat. Gaya yang dihadirkan pun sudah tidak beraya indische empire lagi, dan tidak bergaya kolonial modern. Gaya arsitektur di jaman peralihan ini banyak mengadaptasi iklim Indonesia yang tropis dengan bentukan Belanda yang masih sangat terlihat. Paper ini merupakan hasil penelitian melalui observasi dengan survei di lokasi Perumahan Dinas Militer Angkatan Darat, Cimahi, Jawa Barat. Data dianalisis secara kuantitatif untuk menganalisis jumlah rumah dan ornamen yang telah dibongkar dan bentuk aslinya. Di samping itu metode kualitatif juga digunakan untuk menganalisis pembongkaran-pembongkaran yang dilakukan penghuni kepada bangunan.
\end{abstract}

Kata kunci: Cimahi, perumahan dinas militer, arsitektur peralihan 


\section{PENDAHULUAN}

Semua berawal dari rencana pemindahan ibu kota Hindia Belanda dari Batavia ke Bandung pada tahun 1915, oleh Gubernur Jenderal J.P. de Graaf van Limburg Stirum. Bandung dipilih karena dianggap lebih nyaman dan cocok untuk tempat tinggal warga Eropa. Sejak itu, Belanda mendatangkan banyak arsitek profesional dari negaranya untuk membangun dan menata Bandung.

Sejak tahun 1880-an Cimahi direncanakan sebagai basis militer Pemerintah Kolonial Hindia Belanda, sedangkan Bandung direncanakan sebagai Pusat Kota Pemerintahan Kolonial Hindia Belanda. Awal abad ke 20 ini adalah puncak kekuasaan pemerintahan kolonial Belanda di Indonesia, maka dari itu Belanda pun melengkapi fasilitas untuk angkatan bersenjatanya. Pertama-tama, mereka membangun pusat militer angkatan darat lengkap dengan hunian bagi para prajuritnya. Pusat militer ini dikonsentrasikan di pusat kota Bandung dan Cimahi. Pemerintah Kolonial Hindia Belanda juga membangun Stasiun Kereta Api di Cimahi berkaitan dengan upaya mempertahankan kekuasaan di daerah Bandung Cimahi. Sebagai sarana pengangkutan logistik militer dari Batavia ke Cimahi dan Bandung sekitarnya. Selain Stasiun, komplek militer di Cimahi dilengkapi dengan rumah sakit dan hunian untuk para prajuritnya. Pembangunan komplek militer di Cimahi tersebut diharapkan menjadi protoype bagi pembangunan serupa pada kota garnizun dan komplek militer yang lebih kecil di seluruh nusantara.

Kota Cimahi juga mendapatkan julukan sebagai “Kota Tentara” karena di kota ini terdapat banyak pusat pendidikan untuk tentara, diantaranya: Pusat Pendidikan Artileri (Pusdik Art), Pusat Pendidikan Artileri Medan (Pusdik Armed), Pusat Pendidikan Guru Militer (Pusdik Gumi), Pusat Pendidikan Infanteri (Pusdik In), Pusat Pendidikan Jasmani (Pusdik Jas), Pusat Pendidikan Pal (Pusdik Pal), Pusat Pendidikan Perbekalan dan Angkutan (Pusdik Bekang), Pusdik Pendidikan Polisi Militer (Pusdik Pom), dll. Dengan banyaknya pusat pendidikan dan fasilitas kemiliteran lainnya, sekitar 60\% wilayah Kota Cimahi digunakan oleh kepentingan tentara (Pemerintah Kota Cimahi, 2011). Sampai sekarang Cimahi menjadi pusat peninggalan Belanda di bidang pembangunan gedung-gedung militer. Benda-benda cagar budaya di kota ini kebanyakan memiliki kaitan sangat erat dengan aktivitas dunia kemiliteran. Salah satu contohnya adalah rumah tahanan militer yang berdiri pada tahun 1886. Rumah tahanan ini berada di kawasan Poncol, tidak jauh dari kompleks pusat pendidikan militer. Di Cimahi juga ada rumah sakit militer yang berusia 123 tahun, kolam renang, lapangan tembak, gedung pertemuan, bioskop, stasiun kereta, gereja, hingga kompleks pekuburan. Semua fasilitas tersebut dibangun di komplek militer Cimahi untuk kepentingan militer Belanda pada waktu itu.

\section{METODE}

Penelitian ini menggunakan metode observasi dan survey pada lokasi perumahan Dinas Militer Cimahi, Jawa Barat, serta studi pustaka berkaitan dengan sejarah arsitektur bangunan kota Cimahi. Analisis kuantitatif digunakan untuk menganalisis jumlah rumah dan ornamen yang telah dibongkar dan bentuk aslinya. Di samping itu metode kualitatif juga digunakan untuk menganalisis pembongkaran-pembongkaran yang dilakukan penghuni kepada bangunan.

\section{HASIL DAN PEMBAHASAN}

Abad ke-18 dan 19, arsitektur di Hindia Belanda didominasi oleh gaya Indsche empire. Gaya Arsitektur tersebut dipopulerkan oleh gubernur jendral H.W. Daendels (1808-1811). Ciri ciri khas dari 
arsitektur tersebut yaitu: (1) denah simetris; (2) terdapat central room di tengah yang terdiri dari kamar tidur utama dan kamar tidur lainnya; (3) central room juga berhubungan langsung teras depan dan teras belakang; (4) teras sangat luas ditopang pilar bergaya yunani atau romawi (doric, ionic, cornithian); (5) dapur, kamar mandi atau wc gudang dan daerah servis lainnya merupakan bagian yang terpisah dari bangunan utama dan letaknya di belakang; (6) kadang-kadang di samping bangunan utama terdapat paviliun yang digunakan sebagai kamar tidur tamu; (7) Kalau rumah tersebut berskala besar biasanya terletak pada sebidang tanah yang luas dengan kebun di samping depan dan belakang.

Gaya arsitektur indische empire menghilang pada awal ke 20 di hindia Belanda sebelum munculnya gaya arsitektur kolonial modern, yang biasa dikenal dengan gaya art deco. Kelahiran ArtDeco terjadi di antara dua Perang Dunia, yaitu antara tahun 1920 s.d 1939. Nama Art deco diilhami dari satu pameran Exposition Internationale des Arts Decoratifs Industriale et Modernes yang diadakan di Paris pada tahun 1925. Art deco menunjukkan suatu istilah langgam decoratif yang terbentuk di antara tahun 1920-1930. Art deco menginduk pada modernisme hanya saja lebih fokus ke variasi dekoratif berbagai produk. Karakter yang paling utama adalah bentuk Bentuk Art deco kebanyakan berupa geometrik murni dan Kesederhanaan (Simplicity). Langgam art deco di Bandung dipopulerkan oleh Prof. Ir. Charles Proper Wolff Schoemaker dan A.F.albers. Contoh gaya Art deco di Bandung adalah Vila Isola (1932), yang dirancang oleh CP Wolff Schoemaker.

Arsitek-arsitek yang berkarya di Bandung terpengaruh dengan gaya arsitektur yang tengah populer di Eropa saat itu. sehingga respons terhadap iklim itu sangat terlihat dalam orientasi bangunan dan bentuknya yang mereka sebut tropische art deco. Di antara gaya indische empire dan gaya Art deco itu, ada masa dimana arsitektur mengalami gaya transisi yang dinamakan sebagai arsitektur transisi/peralihan dari indische empire ke kolonial modern (art deco). Arsitektur transisi ini mempunyai bentuk denah yang hampir mirip dengan arsitektur indische empire. Ciri ciri gaya indische empire, seperti: adanya teras depan (voor galerij) dan teras belakang (achter galerij) serta ruang utama (central room), masih mendominasi denah arsitektur transisi ini. Pada rumah rumah yang berukuran besar juga terdapat bangunan samping yang sering disebut sebagai paviliun. Yang jelas terlihat pada arsitektur transisi ini adalah sudah tidak nampaknya kolom kolom atau pilar dengan gaya yunani atau romawi (doric, ionic, cornithian). Arsitektur transisi ini merupakan pembaharuan secara total model arsitektur sebelumnya yang mempunyai gaya indische empire.

Kaum militer Belanda sadar betul akan iklim setempat sehingga mereka menamakan kompleknya dengan istilah "tropenkampenten" (Komplek militer daerah tropis. Di dalam militer Belanda sendiri ada bagian yang bernama korp zeni bangunan, yang bertanggung jawab atas pembangunan komplek militer jaman kolonial.

\section{Hirarki Rumah Dinas Militer}

Disiplin yang tinggi serta hirarki yang ketat adalah salah satu ciri khas kehidupan dalam dunia kemiliteran sehari harinya. Perbedaan hirarki ini tercermin pada bentuk fisik perumahan dalam sebuah komplek militer.Dalam hirarki kepangkatan perwira, berturut turut adalah kolonel, kapten dan letnan. Jadi, rumah dinas seorang kolonel mempunyai luasan yang lebih besar serta tampak yang lebih megah dibanding rumah dinas seorang kapten dan seterusnya.

\section{Rumah Dinas Kolonel}

Rumah dinas kolonel terbagi atas rumah induk dan paviliun. Rumah induk terdiri dari kamarkamar dengan luasan $8 \times 5.5 \mathrm{~m}$. Ada pula voor galerij (teras depan) dan achter galerij (teras belakang). Ruang depan masih digunakan sebagai ruang kerja. Tampak depan sudah tidak mencirikan indische empire. Penataan ruang tidak jauh beda dengan denah-denah bangunan abad ke 19, yaitu denah berbentuk simetris. Penyesuain dengan iklim tropis lembab terlihat pada banyaknya kamar- 
kamar di denah paviliunnya yang biasanya ditempati prajurit pengawal sesuai dengan standar pengamanan dalam dunia militer. Bentuk atap menunjukkan ciri atap khas eropa. Bentuk atap serta sistem pembukaan pada terasnya menggunakan pembukaan bentuk lengkung, yang merupakan ciri khas rumah kolonel. Tampak rumah kolonel dibedakan dengan rumah kapten dan letnan karena hirarki dalam militer yang ketat.

\section{Rumah Dinas Kapten}

Luas denah rumah tinggal kapten lebih kecil dari pada rumah dinas kolonel. Tampaknya juga lebih sederhana sesuai hirarki kemiliteran (Gambar 1). Pada rumah dinas kapten tidak ada paviliun. Denahnya hanya terdiri dari dua banguan yaitu rumah induk dan rumah belakang. Rumah belakang hanya digunakan untuk area servis seperti kamar mandi, dapur dan sebagainya. Antara kedua bangunan ini dihubungkan dengan galeri (Gambar 2).

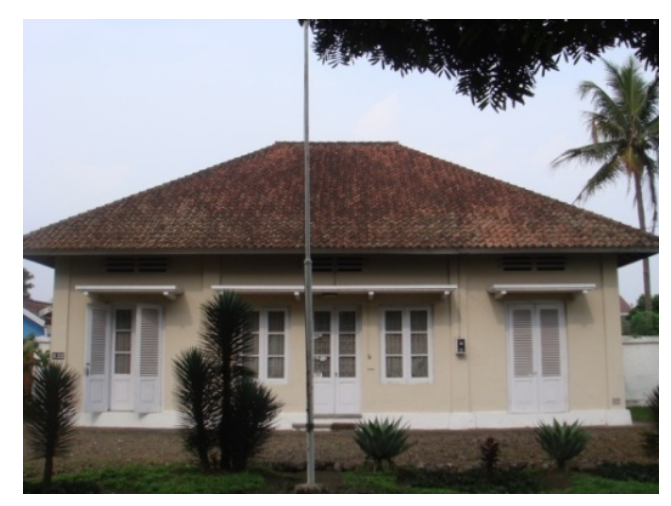

Gambar 1. Tampak depan rumah dinas kapten.

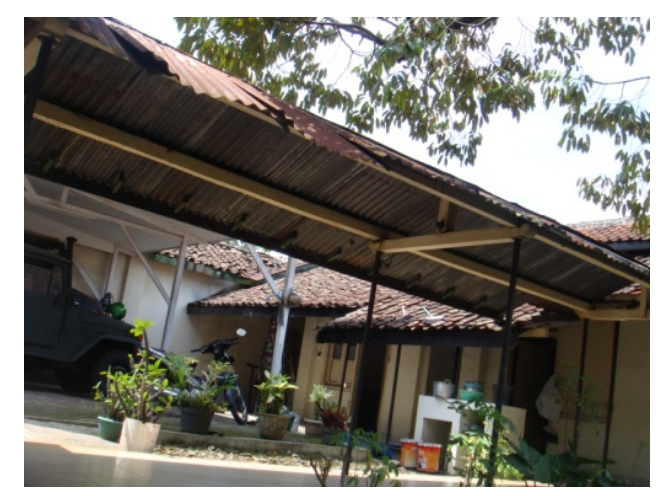

Gambar 2. Galeri penghubung rumah depan dan belakang

Bentuk denah rumah tinggal abad ke-19 dan awal abad ke-20 kebanyakan memisahkan bagian servis dan rumah induk, karena dianggap daerah servis kotor, lembab dan berbau. Bagian ini harus dipisahkan dengan aktivitas sehari hari seperti ruang duduk, ruang makan dan ruang tidur. Pada rumah induk tidak terlalu banyak teras. Meskipun ada teras depan, teras atau galeri belakang lebih sempit dibandingkan teras rumah kolonel. Rumah tinggal seorang kapten memiliki empat buah kamar pembantu yang masing masing berukuran 3 x 3 meter. Sedangkan kamar keluarganya berukuran 5,5 x 5 meter.

\section{Rumah Dinas Letnan}

Rumah dinas letnan merupakan rumah dinas yang terpisah dari hirarki kemiliteran, karena merupakan level terendah kepangkatan jajaran perwira ketentaran. Rumah dinas letnan berbentuk kopel dengan denah berbentuk simetri. Denah dan tampak rumah dinas letnan sama sekali tidak mengacu pada arsitektur indische empire. Atap berbentuk atap pelana dari bahan genting. Rumah letnan tidak seluas rumah kolonel dan kapten, tapi cukup memadai. Bagian servis di belakang dan sampingnya cukup luas. Ada dua buah kamar tidurnya dan sebuah kamar kerja. Di samping rumah induk ada halaman walau tidak terlalu luas. Terdapat pagar keliling yang membatasi rumah dengan bagian lain di komplek militer. 


\section{PENUTUP}

Bangunan-bangunan militer Cimahi ini bergaya arsitektur peralihan dari indische ke art deco sebuah gaya yang mengadaptasi iklim tropis Indonesia ke dalam bentuk bangunan. Saat ini, Pemerintah Kota (Pemkot) Cimahi merancang Kota Cimahi menjadi kawasan wisata heritage, terutama bangunan militer. Upaya itu sebagai salah satu cara untuk melindungi bangunan dan bendabenda cagar budaya di Kota Cimahi yang memiliki potensi wisata. Salah satu nya adalah Pemanfaatan Rumah Dinas Militer, yaitu upaya-upaya yang dilakukan di dalam pemanfaatan gedung atau rumah dinas di kawasan militer Kota Cimahi yang sudah tidak dihuni/dipergunakan lagi untuk dapat diubah fungsikan menjadi: Museum Mini Militer, restoran bertemakan militer, area permainan \& rekreasi, souvenir shop, bioskop mini, dll. Diharapkan dengan pelestarian kawasan heritage militer di Cimahi ini dapat memacu daerah lain untuk melestarikan peninggalan bangunan heritage juga, sebagai salah satu peninggalan sejarah kota.

\section{DAFTAR PUSTAKA}

Handinoto \& Hartono, Samuel. (2006). Arsitektur Transisi di Nusantara dari Akhir Abad 19 ke 20, Dimensi (Jurnal Teknik Arsitektur), 34 (02). Surabaya: Faculty of Civil Engineering and Planning, Petra Christian University.

Pemerintah Kota Cimahi. (2011). Diakses dari http://www.cimahikota.go.id/index.php?option=com_content\&view=article\&id=273:wisatabersejarah\&catid=39:objek-wisata\&Itemid=149 